\title{
Asztmás betegek életminőségének változása komplex rehabilitációs kezelés után
}

\author{
Müller Anetta dr. ${ }^{1}$ - Balatoni Ildikó dr. ${ }^{2}$. Csernoch László dr. ${ }^{3}$ \\ Bács Zoltán dr. ${ }^{4}$ - Bíró Melinda dr. ${ }^{5}$. Elena Bendíková dr. ${ }^{6}$ \\ Pesti Anna dr. ${ }^{7}$ - Bácsné Bába Éva dr. ${ }^{1}$ \\ Debreceni Egyetem, ' ${ }^{1}$ azdaságtudományi Kar, Vidékfejlesztés, Turizmus és Sportmenedzsment Intézet, \\ ${ }^{2}$ Általános Orvostudományi Kar, Klinikai Központ, \\ ${ }^{3}$ Általános Orvostudományi Kar, Élettani Intézet, ${ }^{4}$ Gazdaságtudományi Kar, Számviteli és Pénzügyi Intézet, \\ ${ }^{5}$ Sporttudományi Koordinációs Intézet, Debrecen \\ ${ }^{6}$ Mateja Bela Egyetem, Filozófiai Kar, Sporttudományi Intézet, Banská Bystrica, Szlovákia \\ ${ }^{7}$ Mátrai Gyógyintézet, Pulmonológiai Rehabilitációs Osztály, Mátraháza
}

\begin{abstract}
Az asztma valamennyi korosztály számára világszerte súlyos népegészségügyi kihívást jelent. A természetes gyógytényezők használata a betegségek gyógyításában fokozott figyelmet kap hazai és nemzetközi viszonylatban is, ami a gyógyszeres kezeléseket költséghatékonyabbá teheti. A kutatásunk újszerüsége, hogy igazoljuk: már a 700-1000 méter tengerszint feletti magasságú gyógyhelyen is érvényesül a klíma gyógyhatása. Kutatásunk során arra kerestük a választ, hogyan alakul az asztmások életminősége a klímaterápiával kiegészített orvosi kezelés után, s igazolható-e a 700-1000 méteren végzett klímaterápia hatása idős, felnőtt betegeken. A légzőszervi megbetegedésben szenvedők a Mátrai Gyógyintézetben 3 hetes komplex terápián vettek részt. A jelen cikkben 514 asztmás beteg adatait elemeztük. Az orvosi vizsgálatokon és kezeléseken túl a betegek napi két alkalommal kúrateraszokon vagy a szabadban végzett légzőtornán, valamint napi egy alkalommal gyógytornászok által vezetett gyógytorna-mozgásprogramban, dietetikai és életmód-tanácsadáson vettek részt, továbbá a betegségükhöz igazodó diétás étrend lehetőségét is biztosítottuk számukra. A légzésfunkció vizsgálatát az intézetbe jövetelkor a kúra előtt és az intézetből történő távozáskor, a kúra után végeztük el. A betegek terhelhetőségét a 6 perces járásteszttel mértük fel a kúra előtt, majd 3 héttel később. A betegek részére kérdőívet készítettünk, melyben az intézetből való távozás utáni állapotukra (1-6 hónap) kérdeztünk rá. Eredményeink azt mutatják, hogy az asztmás betegek légzésfunkciós értékei, a 6 perces járásteszt eredményei szignifikánsan javultak a kezelés hatására. Az intézetből való távozás után az Asthma Control Test eredményei a kezelés utáni 1. hónapban a betegek szignifikánsan jobb életminőségét és jobb kontrollszintjét mutatták, mint a 3. hónap elteltével.
\end{abstract}

Orv Hetil. 2018; 159(27): 1103-1112.

Kulcsszavak: életminőség, asztma, klímaterápia

\section{Quality of life of asthmatic patients after complex rehabilitation treatment}

Asthma is a serious public health challenge for all age groups around the world. Heightened attention surrounds the use of the natural therapeutic factors that potentially make medication more cost-efficient in the treatment of diseases. Our research has tried to reveal how the medical conditions, quality of life of asthmatic patients change after medical treatments that are accompanied by climate therapy. Asthma patients (514 patients) participated in a 3-week complex therapy at Mátra Health Resort. Beyond medical examinations and treatments, patients were involved in breathing exercises on the curing terraces or outdoors twice a day, they were to attend the rehabilitative physical exercises led by a physiotherapist once a day, were given dietetic and lifestyle advice and provided with diets that were fitted to their individual medical conditions. Their respiratory function was examined before the commencement of the cure as well as after the therapy just before departing from the institution. The patients' exercise capacities were assessed with the 6-minute walk test before the treatment and then 3 weeks later. For the patients, a questionnaire was compiled to reveal information in relation to their conditions in the first 6 months after leaving the institution. 
Our results show that values of respiratory function in the sample and 6-minute walk test significantly improved with the treatment. After leaving the institute, the results of the Asthma Control Test in the lst month after treatment revealed a significantly better quality of life and better control-level of patients than after the 3rd month.

Keywords: quality of life, asthma, climatotherapy

Müller A, Balatoni I, Csernoch L, Bács Z, Bíró M, Bendíková E, Pesti A, Bácsné Bába É. [Quality of life of asthmatic patients after complex rehabilitation treatment]. Orv Hetil. 2018; 159(27): 1103-1112.

(Beérkezett: 2018. január 8.; elfogadva: 2018. március 5.)

\begin{abstract}
Rövidítések
$6 \mathrm{MWT}=($ six-minute walk test $)$ hatperces járásteszt; ACT = (Asthma Control Test) Asztma Kontroll Teszt - az asztmások életminőségét, kontrollszintjét mérő kérdőív; BMI = (body mass index) testtömegindex; BORG-féle skála $=0$-10-es skála, amelyen a beteg maga jelzi a nehézlégzés mértékét; COPD = (chronic obstructive pulmonary disease) idült obstruktív tüdőbetegség; $\mathrm{df}=($ degree of freedom $)$ szabadságfok; FEVl $\%=$ (forced expiratory volume timed 1.0 second) az első másodperc alatt kilégzett levegő mennyisége, a referenciaérték \%-ában megadva; FEVl/FVC = (forced vital capacity in 1 second/ forced vital capacity) a FEVl és a vitálkapacitás hányadosa; $\mathrm{HrQoL}=$ (health-related quality of life) egészséggel összefüggô életminőség; ICS = (inhaled corticosteroids) inhalációs kortikoszteroid, asztmások gyógyszere; LABA = (long-acting beta2-agonists) inhalációs hosszú hatású béta-agonista, hosszú hatású $\beta 2$-agonista, asztmások gyógyszere; NHP = (Nottingham Health Profile) általános életminőséget mérő kérdőív; PEFR $=($ peak expiratory flow rate $)$ erőltetett kilégzési csúcsáramlás; $\mathrm{QoL}=$ (quality of life $)$ életminőség; RAQoL $=($ Rheumatoid Arthritis Quality of Life) betegspecifikus kérdőív; sd = standard deviáció; SGRQ $=($ St. George's Respiratory Questionnaire); az asztmások életminőségét mérő teszt; SPSS = statisztikai program; VC = vitálkapacitás; $\mathrm{WHO}=($ World Health Organization) Egészségügyi Világszervezet
\end{abstract}

Az asztma valamennyi korosztály számára világszerte súlyos népegészségügyi kihívást jelent. 2006-ban már közel 200 millió embert érintett világszerte ez a megbetegedés, prevalenciáját 1-18\% között adták meg. Azóta az asztma és az egyéb obstruktív tüdőbetegségek előfordulása sajnos további növekedést mutatott. A 'The Global Asthma Report' (2014) jelentése szerint az asztmások száma 2011-ben 235 millió fő volt, ami 2014-re már 334 millió före emelkedett. Magyarországon is hasonló tendencia figyelhető meg. 2005-ben 196 ezer volt a tüdőgondozói hálózatban nyilvántartott asztmások száma, míg a 10 évvel korábbi adatok alapján ez a szám csak 78 ezer volt [1]. Ezek az adatok azóta is folyamatos növekedést mutatnak. 2015-ben hazánkban közel 300 ezer asztmás gyermeket és felnőttet tartottak nyilván, jelentős azonban azok aránya, akik nem ismerik fel a tüneteket, ezért nem fordulnak orvoshoz betegségükkel. Az elmúlt években nemcsak a betegek száma növekedett, de a kór kialakulása egyre fiatalabb korban jelentkezik. Becslések szerint az asztmás betegek száma 2025-re akár a másfél- szeresére nőhet, ezáltal elérve a 400-450 milliós betegszámot világszerte [2].

Az asztma nemi prevalenciájában a nők magasabb arányát figyelhetjük meg. Ez a betegség 2007-ben a leggyakrabban a nők 55-64 éves korcsoportjában fordult elő, korosztályuk 4\%-át érintette, míg a férfiaknál ez csak 1,9\% (ami országosan és az észak-magyarországi régióban egyaránt igaz) [3].

A légúti megbetegedések növekvő számának egyik oka a fokozott környezeti ártalmak és a légszennyezések globalizációja. A természetes gyógytényezők használata a betegségek gyógyításában fokozott figyelmet kap hazai és nemzetközi viszonylatban is, ami a gyógyszeres kezeléseket költséghatékonyabbá teheti. A légúti betegségek kezelésében számos gyógytényező hasznosítható: klíma, barlang vagy a tengerpart sós levegője. Európa magashegységei (az Eurázsiai-hegységrendszer tagjai) kiváló lehetőségeket nyújtanak a légúti betegségek gyógyításában. Jó példa erre Svájc, ahol a három-négy ezer méteres csúcsokon lévő síterepeket kiszolgáló turisztikai szálláshelyek nyáron klimatikus gyógyüdülőként funkcionálnak (St. Moritz, Davos, Arosa, Saas-Fee, Pontresina, Interlaken).

Hazánkban a légúti betegségek gyógyításában gyógybarlangjaink és hegységeink játszhatnak meghatározó szerepet. A Mátra mint az ország legmagasabb hegye az Északi-középhegység része, mely a Kárpátok belső vulkáni övezetének, így az Eurázsiai-hegységrendszernek a tagja - a leginkább alkalmas az asztmások, allergiások kezelésére. Kékestető gyógyturizmusa, klímaterápiás hotelja a hazánkban egyedi szubalpin klímának, kedvező természeti erőforrásainak köszönheti vonzerejét.

Az életminőség (QoL - quality of life) nehezen meghatározható és igen tágan értelmezett fogalom, mely az egyén jóllétének azon fizikai, szociális és emocionális aspektusait foglalja magában, amelyek az egyén számára fontosak vagy relevánsak [4-6]. Az egészséggel összefüggő életminőség fontossága kerül előtérbe az egészségesek [7] és a betegek esetében (HrQoL - health-related quality of life). Ezen a beteg egészségi állapotának azon hatásait értjük, melyek az életminőséget befolyásolják, hatnak rá. Az egészséggel összefüggő életminőség tehát specifikusan a személy egészségére fókuszál, illetve olyan cselekedetekre, amelyek az egészség megőrzésére, illetve az állapot javítására törekednek [4-6]. Orvosi értelem- 
ben véve az életminőség a betegség funkcionális hatását és a terápiás kezeléseket jelenti egy adott páciensnél, mégpedig úgy, ahogyan azt a páciens fogadta [5]. Az életminőség-vizsgálatok, melyek a leggyakrabban kérdőívvel történnek, megpróbálják számszerüsíteni, tudományosan elemezhető paraméterekkel jellemezni egy megbetegedés vagy terápiás eljárás hatását a beteg egészségére. Az általános (generikus) életminőséget mérő kérdőívek multidimenzionálisak, bármely betegségcsoportban alkalmazhatók, lehetővé téve az összehasonlítást az eltérő betegségcsoportok között - például Euro-Qol (EQ-5D), Nottingham Health Profile (NHP), Short Form 36 (SF-36), Quality of Well-Being [4, 7, 8]. A betegségspecifikus életminőséget mérő kérdőívek egy adott betegségnek a páciens életminőségére gyakorolt hatását vizsgálják. Részletesebb információt adnak a betegségnek az egyénre kifejtett hatásáról. Ezeken a kérdőíveken nagyobb hangsúlyt kapnak a betegségcsoportokra jellemző tünetek (például asztmás betegeknél a gyakran jelentkező nehéz levegővétel). Betegségcsoportok esetében ezek a kérdőívek jobban hasznosíthatók, mint az általános életminőséget vizsgáló kérdőívek, mivel jobban tükrözik a beteg állapotát, és figyelembe veszik a jelentkező tüneteket [6]. A betegségspecifikus tesztek - a St. George's Respiratory Questionnaire (SGRQ), a Rheumatoid Arthritis Quality of Life (RAQoL) [5], így az asztmások állapotát jelző Asztma Kontroll Teszt (ACT) - igen gyakran használt állapotmérő eljárások. Jelen tanulmányunkban ez utóbbi betegségspecifikus életminőséget mérő kérdőívet használtuk fel.

\section{A kutatás célkitüzései}

Elsődleges célunk volt, hogy az intézeti kezelés során elért eredményeket megvizsgáljuk, s utánkövetéses (kérdőíves) vizsgálattal igazoljuk, hogy a Mátrai Gyógyintézet mátraházai és kékestetői egysége a légzőszervi betegek gyógyításában jelentős szerepet játszik, a betegek életminőségét javítja, valamint csökkenti gyógyszerigényüket. Célunk volt megvizsgálni, hogyan alakul az asztmás és allergiás betegek gyógyulása és életminősége 3 hetes, komplex klímaterápiával kiegészített orvosi kezelés után. Kíváncsiak voltunk, hogy a klímaterápiás kezelés hatása meddig érezhető, s igazolható-e a 700-1000 méteren végzett klímaterápia hatása idős, felnőtt betegeken. Úgy véltük, hogy a már 700-1000 méteres tengerszint feletti magasságon is érvényesülő magaslati klíma a légzőszervi betegek gyógyításában jelentős szerepet játszik, a betegek életminőségét javítja, valamint csökkenti gyógyszerigényüket.

\section{Anyag és módszer}

$\mathrm{Az}$ asztmások, szénanáthások és COPD-s betegek körében orvosi háttérrel támogatott kutatást végeztünk. A vizsgálat a Mátrai Gyógyintézetben 2 pulmonológus szakorvos, 4 gyógytornász és 2 dietetikus bevonásával zajlott. Az intézetben 3 hetes komplex terápián vettek részt a betegek. A gyógyintézetbe beutalt betegek esetében a gyógytorna rutinterápiának számít, míg a beteg gyógyszeres terápiája saját, azaz egyedi gyógyszeres, inhalatív terápia volt. Az orvosi vizsgálatokon és kezeléseken túl a páciensek napi két alkalommal kúrateraszokon vagy a szabadban végzett légzőtornán, napi egy alkalommal gyógytornászok által vezetett gyógytorna-mozgásprogramban, dietetikai és életmód-tanácsadáson vettek részt, és a betegségükhöz igazodó diétás étrend lehetőségét is biztosítottuk. A betegek egy része önkéntesen heti 2 alkalommal a kúraútvonalon vezetett alacsony intenzitású „gyalogtúrát”, sétatúrát is kipróbálhatta. A betegeknek felmértük a testsúlyát és testmagasságát, melyekből BMI-t számítottunk. A BMI mérése és besorolása már évtizedek óta használatos és elfogadott mérőeszköz az optimális testsúly vagy akár a túlsúly megállapítására [9]. A WHO által 1995-ben megfogalmazott mérési metodika során kialakított kategóriák napjainkra kissé módosultak (az optimális BMI a felnőttek számára 18,5-24,9 közötti érték). A hazai orvosi kutatások $[10,11]$, melyek az elhízást mérik, szintén a 25ös BMI fölötti értéket veszik alapul a túlsúlyosak és a 30 fölötti értéket az elhízottak kategóriájának kialakításához.

A légzésfunkció vizsgálatát (FEVl, FEVl/FVC) az intézetbe jövetelkor a kúra előtt és az intézetből történő távozás előtt, a kúra után is mértük, a betegek terhelhetőségét pedig a 6 perces járásteszttel mértük fel a kúra előtt, majd 3 héttel később. A FEVI/FVC adatok esetében a 70\% alatti érték kórosnak, a 80-100\%-os érték jónak tekinthető az általunk vizsgált betegek életkori csoportjában. A FEVl/FVC normálértékeket a szakirodalom az életkori csoportoknak megfelelően adja meg: a 19 éves kortól (normálérték 85\%) egészen a 80 éves korig (normálérték 70\%) meghatározásra kerültek az elfogadott értékek. Ezenkívül még az asztma súlyosságának megfelelően is 60-80\%-os FEVl/FVC értéktartományt jelöl ki [12]. Hazai kutatás [13] arról számol be, hogy az asztmás és a COPD-s betegek FEVI/FVC ajánlott értékei hasonlóak. A légzésfunkciós vizsgálatok megközelítésével foglalkozó szakirodalom [14] részletesen bemutatja a FEVl/FVC mérésének és értelmezésének a metodikai hátterét. Az intézetben történő tartózkodás során mindenki használta a rendszeres egyéni inhalatív kezelést. Az ICS vagy ICS + LABA rövid hatású szert $[15,16]$ azonban a légzésfunkciós vizsgálat előtt 12 órával senki nem használta. A légzésfunkciós értékek mérése PDT-111/P típusú géppel (Piston Kft., Budapest) történt.

A hatperces sétateszt ( $6 \mathrm{MWT}$ ) egy szubmaximális edzésprogram, amely értékeli a testmozgásba bevont összes testrendszer összesített és integrált válaszát, beleértve a légzőrendszert, a szív- és érrendszert, a perifériás és szisztémás keringést, a vért, a neuromuscularis egységet és az izmok metabolizmusát [17]. A 6 perces járástesztet több kutatás is alkalmazza az asztmások [18, 19], 
de más betegek rehabilitációjában is, hiszen költséghatékony és szinte bárhol kivitelezhető. A 6 perces járásteszt ajánlásait megfogalmazták (ATS statement: guidelines for the six-minute walk test), amelyben bemutatásra kerülnek azok a tényezők, melyek pozitívan vagy akár negatívan befolyásolhatják a teszt eredményét a betegségen túl (ilyen lehet a testsúly, az életkor, a nem) [20].

A betegek részére kérdőívet készítettünk, melyben az intézetből való távozás utáni állapotukra (1-6 hónap), gyógyszerigényük alakulására kérdeztünk rá (ACT). A kérdőívet kitöltő betegek az intézetbe jöttek terápiás kezelésre, a mért adataik ott kerültek kitöltésre, majd a kérdöívet hazavitték, és otthon töltötték ki, majd postai úton visszaküldték az intézetbe.

Az Asztma Kontroll Teszt öt tételből álló önkitöltős kérdőív; a kérdések között szerepeltek azok, amelyek az asztmás állapot hatását vizsgálták különböző tényezőkre (a munkavégzésre, a levegővételre, az alvásra, a rohamol- dó gyakoriságának használatára és az asztmás állapotára). A kérdéseket az intézetből való távozás után fél éven keresztül minden hónapban kitöltötték a betegek, ezek eredményeit az 1. táblázat szemlélteti. A nehézlégzést vizsgáló módszer a BORG-skála, amelyen a beteg maga jelzi a nehézlégzés mértékét: a 0 azt jelenti, hogy nincs fulladás, míg a 10-es az extrém súlyos eset [21].

Az ACT asztmásokra kifejlesztett validált kérdőív, mely alkalmas klinikai közegben is arra, hogy segítse az orvosokat és a betegeket az asztmás állapot (kontrollszintek: nem kontrollált, alacsonyan kontrollált, részben kontrollált, jól kontrollált, teljes mértékben kontrollált) diagnosztizálásában [22]. Ezzel a teszttel az asztmás állapot szintjét lehet azonosítani. Az 5 pontból álló kérdőív méri az asztma jelentkező tüneteit (éjszakai, nappali), a gyógyszerhasználatot, az asztmás tünetek hatását a mindennapi életre. Az 5 kérdésre 1-5-ös Likert-típusú skálán kell válaszolni, mely értékek összeadódnak. Az

1. táblázat Az Asztma Kontroll Teszt kérdéseinek eredményei

\begin{tabular}{|c|c|c|c|c|c|c|}
\hline & 1. hónap & 2. hónap & 3. hónap & 4. hónap & 5. hónap & 6. hónap \\
\hline \multicolumn{7}{|c|}{$\begin{array}{l}\text { Az asztmás tünetek hatása a munkavégzésre } \\
\text { „Az elmúlt } 6 \text { hónapban milyen gyakran korlátozta Önt asztmája a munkahelyi, iskolai vagy ot } \\
\text { A kérdéseket az alábbi válaszkategóriákkal segitettük: } 1=\text { folyamatosan, } 2=\text { gyakran, } \\
3=\text { néha, } 4=\text { ritkán, } 5=\text { soha }\end{array}$} \\
\hline Átlag & 3,79 & 3,65 & 3,24 & 2,89 & 2,53 & 2,36 \\
\hline Szórás & 0,965 & 1,009 & 1,043 & 1,014 & 0,999 & 1,019 \\
\hline \multicolumn{7}{|c|}{$\begin{array}{l}\text { A nehéz levegővétel gyakoriságának alakulása } \\
\text { „Az elmúlt } 6 \text { hónapban milyen gyakran érzett asztmája miatt nehézséget levegövételkor?” A kérdéseket az alábbi válaszkategóriákkal segitettiuk: } \\
1=\text { naponta többször, } 2=\text { naponta egyszer, } 3=\text { heti } 3-6 \text { alkalommal, } 4=\text { heti } 1-2 \text { alkalommal, } 5=\text { egyszer sem }\end{array}$} \\
\hline Átlag & 3,72 & 3,61 & 3,2 & 2,91 & 2,53 & 2,35 \\
\hline Szórás & 1,169 & 1,134 & 1,144 & 1,122 & 1,179 & 1,199 \\
\hline \multicolumn{7}{|c|}{$\begin{array}{l}\text { Az asztmás tünetek hatása az alvásra } \\
\text { „Az elmúlt } 6 \text { hónapban hány alkalommal ébredt fel éjszaka vagy a szokásos reggeli ébredési idöpontjánál korábban asztmás tünetei miatt? } \\
\text { (Sípolás, köhögés, nehézlégzés, szoritó érzés vagy fájdalom a mellkasban.)” } \\
\text { A kérdéseket az alábbi válaszkategóriákhal segitettük: } 1 \text { = hetente legalább } 4 \text { éjszaka, } 2=\text { hetente } 2-3 \text { éjszaka, } 3=\text { heti } 1 \text { alkalommal, } \\
4=\text { bavonta } 1-2 \text { alkalommal, } 5=\text { egyszer sem }\end{array}$} \\
\hline Átlag & 4,09 & 3,95 & 3,54 & 3,19 & 2,87 & 2,79 \\
\hline Szórás & 1,283 & 1,291 & 1,286 & 1,333 & 1,347 & 1,351 \\
\hline \multicolumn{7}{|c|}{$\begin{array}{l}\text { Asztmás betegek rohamoldó-használatának gyakorisága } \\
\text { „Az elmúlt } 6 \text { hónapban milyen gyakran használt rohamoldót?” E kérdésre az alábbi válaszkategóriákat adtuk: } \\
1=\text { naponta legalább } 3 \text { alkalommal, } 2=\text { napi } 1-2 \text { alkalommal, } 3=\text { heti } 2-3 \text { alkalommal, } \\
4=\text { heti } 1 \text { alkalommal, } 5=\text { egyszer sem }\end{array}$} \\
\hline Átlag & 4,24 & 4,1 & 3,75 & 3,53 & 3,26 & 3,06 \\
\hline Szórás & 1,122 & 1,177 & 1,227 & 1,286 & 1,349 & 1,381 \\
\hline \multicolumn{7}{|c|}{$\begin{array}{l}\text { Asztmás betegek állapotának alakulása a Mátrai Gyógyintézetben történt kezelés után } \\
\text { „Összességében hogyan értékeli asztmás állapotát az elmúlt } 6 \text { hónapban?” E kérdésre az alábbi válaszokat jelöllhették a betegek: } \\
1=\text { egyáltalán nem vagyok jól, } 2=\text { nem vagyok jól, } 3=\text { közepesen érzem magam, } \\
4=\text { jól érzem magam, } 5=\text { teljesen jól érzem magam }\end{array}$} \\
\hline Átlag & 4,02 & 3,09 & 3,43 & 3,13 & 2,8 & 2,56 \\
\hline Szórás & 0,933 & 0,894 & 0,948 & 0,933 & 0,882 & 0,954 \\
\hline \multicolumn{7}{|c|}{ Az Asztma Kontroll Teszt összpontszámának átlagértékeinek alakulása a kezelés utáni 1-6. hónapban } \\
\hline Pontszám & 19,86 & 19,2 & 17,16 & 15,65 & 13,99 & 13,2 \\
\hline
\end{tabular}


ACT-felmérés során 5 és 25 pont közötti értéket lehet elérni: az 5 pont a rosszul kontrollált asztmás állapotot, a 25 pont a teljeskörúen kontrollált asztmás állapotot, azaz a legjobb értéket jelenti.

A kérdőívek eredményeit az SPSS 22.0 szoftver segítségével dolgoztuk fel. Számítottunk átlagot, szórást, medián és módusz értékeket. Az összefüggések vizsgálatára Pearson-féle khi-négyzet-próbát és paired samples tesztet használtunk.

\section{A minta szociodemográfiai adatai}

A felmérésben 678 vizsgált beteg vett részt (asztma, COPD, rhinitis allergica). A felmért mintában 522 fó volt az asztmás beteg, akiket vizsgálunk, ebből 514 kérdőív volt használható. A minta 13,2\%-a (68 fö) férfi, míg 86,8\%-a (446 fő) nő volt. A vizsgált asztmás mintában a betegek 11,1\%-a (57 fó) érkezett faluról, a legtöbben 36,4\% (187 fó) városban élnek. Igen jelentős a megyeszékhelyről, azaz nagyvárosból érkező betegek aránya, 35\% (180 fó). Budapestről a betegek 16,9\%-a (87 fó) érkezett. A mintában a városlakók dominanciája figyelhető meg: ez összefügghet a városok szennyezettebb levegőjével, amely a különböző asztmás, allergiás és egyéb légúti tüneteket indukálja. A Mátrai Gyógyintézetbe a betegek a tüdőgondozókban kiállított beutalóval, beutalási sorrendben érkeztek.

Szakirodalmi adatok bizonyítják, hogy a falvakban az asztma, az asztmás tünetek kevésbé fordulnak elö, mint a városi területeken [23]. Az asztma kapcsán számos környezeti kockázati tényezőt tulajdonítottak mind a fejlett, mind a fejlődő országokban tapasztalható erőteljes gazdasági növekedésnek. Az asztma növekedésével járó egyik legfontosabb kockázati tényező a gépjármúvek számának emelkedéséből [24] és a bizonyos ipari folyamatok jelenlétéből adódó levegőszennyezés növekedése [25]. A Levegő Munkacsoport és nemzetközi kutatások is felhívják a figyelmet arra, hogy a téli időszakban a lakosság fütésével kapcsolatos légszennyezettség egyes falvakban sok esetben extrém módon meghaladja a gépjármúvek által kibocsátott értékeket [26-28].

A vizsgált mintában a nem dohányzók magas százalékos arányát tapasztaltuk ( $88,9 \%-457$ fó); a válaszadók 7\%-a (36 fó) nyilatkozta, hogy dohányzik, míg 3,5\% (18 fó) mondta, hogy alkalmanként. A dohányzás nagyban befolyásolja a légzőszervek állapotát egészséges emberekben is. Az asztmások, allergiások és COPD-s betegek állapotát rontja a dohányzás, amit hazai és nemzetközi publikációk is bizonyítottak. Különösen fontos tehát az előbb említett tények miatt, hogy ezek a betegek ne dohányozzanak. Úgy véljük, ez az adat, hogy a Mátrai Gyógyintézetben kezelt asztmás betegek 88,9\%-a nem dohányzik, kedvezőbbnek mondható, mint amiről más hazai kutatás számol be. Igaz ugyan, hogy ennek a kedvező képnek oka lehet a magas átlagéletkor és a nók dominanciája a mintában. Gállfy és mtsai [29] hazai felnőtt asztmás betegek körében végzett kutatásukban beszá- molnak a betegek asztmakontrollszintjének meghatározásáról, valamint az azt befolyásoló tényezők felderítésérôl. Az általuk vizsgált mintában az asztmás betegek 14\%-a a vizsgálat idején is aktív dohányos volt, és az öszszes beteg $41 \%$-a dohányzott egykor.

Az asztmás betegek átlagéletkora 59,9 év volt, melyhez nagy szórásérték $(8,2)$ társult. A legfiatalabb beteg 37 éves, míg a legidősebb 81 éves volt. A mintában a magas átlagéletkornak köszönhetően nagy volt a nyugdíjasok aránya, hiszen a válaszadók $72,4 \%$-a nyilatkozta ezt; közülük 13,2\% rokkantnyugdíjas volt. Fontos mérni a betegek testmagasságát és testtömegét is, illetve az ebből számított BMI-t [30]. A vizsgált betegek átlagos testtömege $78,0 \mathrm{~kg}$ volt (szórás $=15,35$ ) és átlagos testmagasságuk 163,3 cm (szórás = 9,16); az átlagos BMI 29,5 (sd = 5,1), ami a túlsúlyos betegek dominanciájára utal. Az elhízás, a kóros kövérség (obesitas), mely hazánkban is már szinte népbetegséggé vált, kedvezőtlenül befolyásolja a légzőszervi betegek életminőségét. A mintában mind a férfi, mind a nóbetegek közel azonos, igen magas arányban túlsúlyosak. A férfiak 89,2\%-ának (58 fö) BMI-értéke 25 fölötti szám, míg a nők 79,0\%-a (350 fó) tartozik ebbe a kategóriába. A betegek kisebb része, a férfiak 10,8\%-a és a nők 19\%-a mondhatja el magáról, hogy testtömege optimális.

A légzőszervi rehabilitációban részt vett betegek a diagnózis szerint asztmában, rhinitis allergicában (szénanátha) szenvedtek, vagy COPD-s betegek voltak. Ezek a betegségek sok esetben nem önállóan jelentkeznek, hanem társultan voltak jelen a betegeknél. A leggyakrabban előforduló betegség az asztma, hiszen a minta 77\%-nál (522 fó) diagnosztizálták. COPD-ben szenved vizsgált betegeink 34,5\%-a (234 fó), és közel azonos arányt figyelhetünk meg a rhinitis allergica esetében: betegeink 33,2\%-át (225 fó) sújtja ez a betegség. Az asztmával leggyakrabban társuló légzőszervi betegség a rhinitis allergica, hiszen betegeink 26,5\%-ánál (180fő) egyszerre mindkét betegség diagnosztizálható. Az asztmások és egyben COPD-s betegek a vizsgált minta 13,7\%-át (93 fó) adják. A legkevésbé gyakori a COPD és a rhinitis allergica együttes előfordulása, mivel ez betegeinknek csupán az 5,3\%-át (36 fó) érintette (2. táblázat).

2. táblázat $\mid$ A vizsgált minta betegségeinek alakulása (fó)

\begin{tabular}{l|ccc}
\hline \multirow{2}{*}{ Diagnózis } & \multicolumn{3}{|c}{ A mintában előforduló betegségek (fó) } \\
\cline { 2 - 4 } & Asztma & $\begin{array}{c}\text { Rhinitis } \\
\text { allergica }\end{array}$ & COPD \\
\hline Asztma & 249 & 180 & 93 \\
Rhinitis allergica & 180 & 9 & 36 \\
COPD & 93 & 36 & 105 \\
\hline Összes & 522 & 225 & 234 \\
\hline
\end{tabular}




\section{A háromhetes komplex klímaterápia hatásának eredményei asztmás és allergiás betegeknél}

A 3 hetes komplex klímaterápia során felmértük az asztmás betegek $(\mathrm{N}=522)$ állapotát az intézetbe kerüléskor, majd a 3 hetes kúra után. A vizsgált paraméterek között a FEV1\%-os és a FEVl/VC adatokkal a légzésfunkciót vizsgáltuk, a 6 perces járásteszttel pedig az asztmás betegek terhelhetőségét. Az asztmás betegeknek a FEV1\%-os átlagértéke az intézetbe jövetelkor 72,188 ( $\mathrm{sd}=23,6)$ volt, a terápia hatására a 3 . hét végére ez 78,34-ra $(\mathrm{sd}=$
22,7) emelkedett, ami szignifikáns javulást jelent (páros t-próba: $\mathrm{p}<0,001, \mathrm{t}=11,38, \mathrm{df}=503)$. A FEVI $/ \mathrm{VC}$ intézetbe jöveteli átlagértéke $88,6(\mathrm{sd}=17,27)$ volt, mely a 3 . hét után 91,78 -ra $(\mathrm{sd}=15,14)$ javult $(\mathrm{p}<0,001$, $\mathrm{t}=5,602, \mathrm{df}=479)$. A hatperces járásteszt eredménye $\mathrm{az}$ intézetbe jövetelkor $379,8 \mathrm{~m}(\mathrm{sd}=106,59)$ volt, a 3 . hét után $456,98 \mathrm{~m}$-re $(\mathrm{sd}=110,97)$ javult $(\mathrm{p}<0,001, \mathrm{t}=$ $7,862, \mathrm{df}=93$ ).

Kíváncsiak voltunk arra, hogy a kezelés hogyan hat a különböző életkorú és nemú betegekre. Az eredményeket az 1., a 2. és a 3. ábra szemlélteti: a vízszintes tengelyen az egyének életkora van feltüntetve, a függőleges

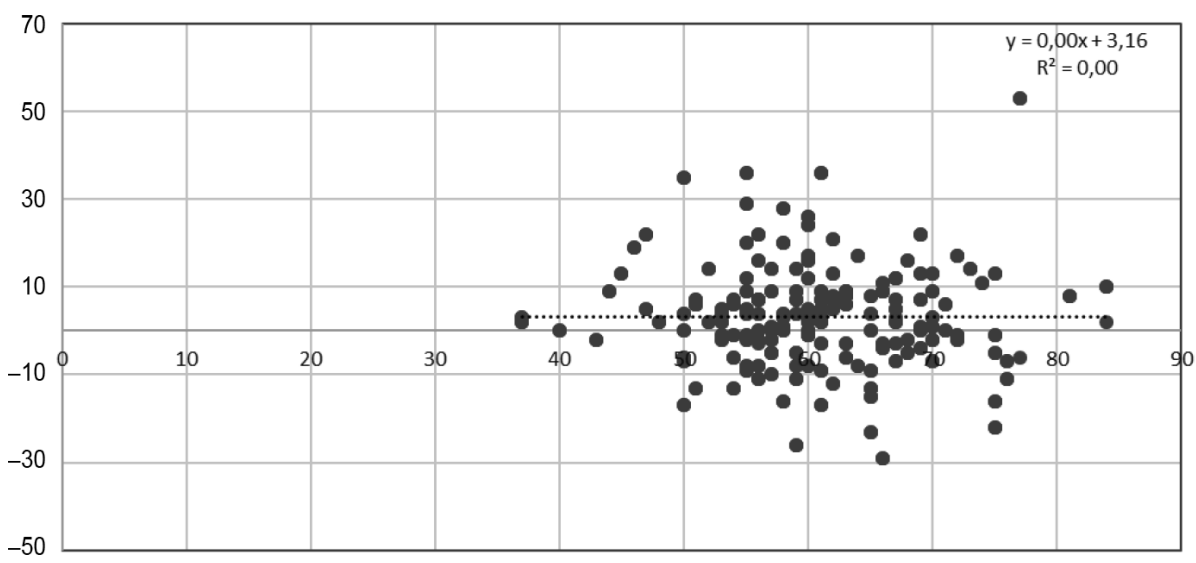

1. ábra A vizsgált asztmás minta FEVI/VC különbségének alakulása az életkor tükrében az intézetbe jövetelkor és az intézetből való távozás után

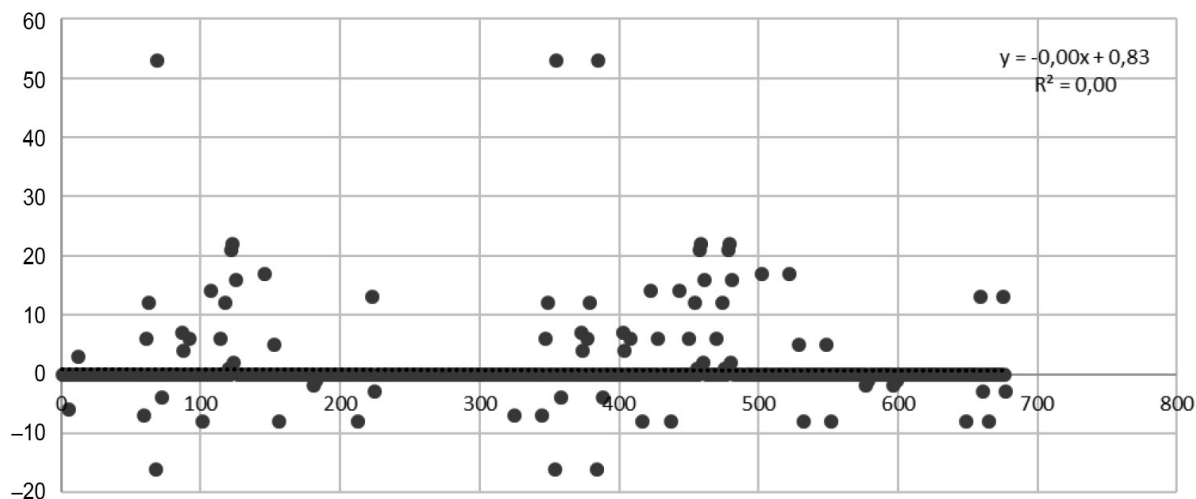

2. ábra |A vizsgált asztmás minta FEVI/VC különbségének alakulása a férfimintában az intézetbe jövetelkor és az intézetből való távozás után

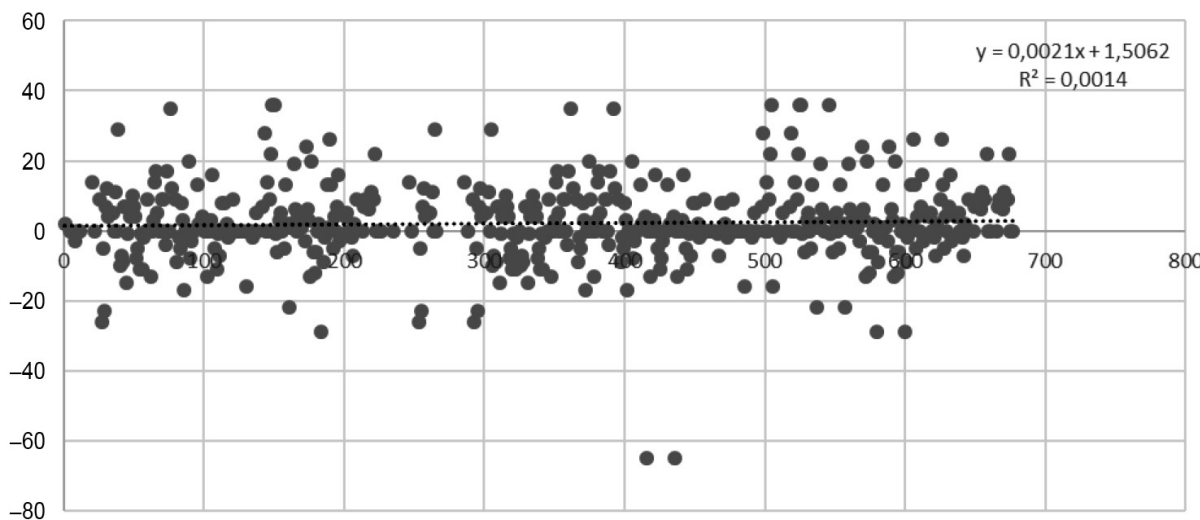

3. ábra $\quad$ A vizsgált asztmás minta FEVl/VC különbségének alakulása a női mintában az intézetbe jövetelkor és az intézetből való távozás után 
tengelyen a FEVI/VC változása, mely az intézetből való távozáskor és a bejövetelkor mért értékek különbségeit mutatja. Az adatok azt igazolják, hogy a terápia minden életkorú vizsgálati személynél ugyanazt az eredményt mutatja, az életkor szerint nem mutatható ki igazolt különbség a terápia hatását illetően (1. ábra). Kíváncsiak voltunk a FEVI/VC érték változására a nemek tükrében is (2. és 3. ábra). Eredményeink azt mutatták, hogy mind a férfiak, mind a nók esetében hasonlóan kedvező volt a terápia hatása. A légzésfunkciós értékeknél megfigyelhetjük a férfiak és a nők mintájában is, hogy bizonyos betegek esetében az intézetbe kerüléshez képest a FEVI/VC értéke 3 hét elteltével romlott. Mivel ez egyszeri légzésfunkciós mérés, a terápia után mért kedvezőtlenebb értéknek oka lehet akár az időjárás, a hely mikroklimatikus viszonya (például párásabb levegő) vagy esetleg a rossz fújástechnika is. Az ábrákon az is látható, hogy a nők előfordulása sokkal magasabb volt a mintában, amit az asztma nők körében megfigyelhető nagyobb aránya önmagában nem magyarázhat. Véleményünk szerint ennek további oka lehet, hogy a nók gyakrabban fordulnak orvoshoz, és nagyobb hajlandóságot mutatnak a terápiás kezelésre.

Az asztmások állapotát a nemzetközileg validált Asztma Kontroll Teszttel vizsgáltuk.

Az 1-5-ös gyakorisági skálán tehát a nagyobb pontszám jelzi a beteg kedvezőbb állapotát. Az eredmények azt mutatták, hogy a kezelés utáni 1. hónapban az átlagérték 3,79 volt, vagyis a 4-eshez közelített, tehát a ritkább asztmás tünet volt tapasztalható, míg a 6 . hónap elteltével 2,36-ra csökkent az átlagérték, mely az első hónaphoz képest az asztmás tünet gyakoribb előfordulását mutatja (1. táblázat). A kezelés utáni hónapokban az átlagértékekhez magasabb szórásértékek társulnak, ami mutatja, hogy a betegek válaszai, állapotuk nem egységes. Amennyiben összehasonlítottuk páros t-teszttel a kezelés utáni elsó és a 3 . hónap $(\mathrm{t}=18,11, \mathrm{df}=516$, $\mathrm{p}<0,001)$, illetve a 3 . és a 6 . hónap eredményeit $(\mathrm{t}=$ $21,23, \mathrm{df}=513, \mathrm{p}<0,001)$, rendre szignifikáns eltérést kaptunk. Az asztmás betegeket az intézetből való távozás után egyre jobban korlátozták asztmás tüneteik, azaz állapotuk romlott.

Az asztmás betegek nehézlégzésének előfordulási gyakoriságában (melyet a beteg maga értékelt, hasonlóan a Borg-skálás értékeléshez) hasonló eredményeket kaptunk. A Mátrai Gyógyintézetben történt terápiás kezelés hatása eredményesnek bizonyult, hiszen a betegek a távozás utáni 1 . és 2 . hónapban ritkábban tapasztalták a nehéz levegővételt, mint a távozás utáni 5 . és 6 . hónapban (1. táblázat). Valamennyi hónapban magas szórásértéket tapasztaltunk, vagyis nem egységesek a válaszok, a betegek állapotában jelentkező „nehézlégzés” tünet előfordulási gyakorisága között nagy egyéni eltérések tapasztalhatók. Amennyiben összehasonlítottuk páros tteszttel a nehéz levegóvételre vonatkozóan a kezelés utáni 1. és 3 . hónap eredményeit $(\mathrm{t}=14,49, \mathrm{df}=515$, $\mathrm{p}<0,001)$, illetve a 3 . és a 6 . hónap eredményeit $(\mathrm{t}=$
$17,15, \mathrm{df}=515, \mathrm{p}<0,001)$, rendre szignifikáns eltérést kaptunk. Az asztmás betegek nehéz levegővétele, annak gyakorisága az intézetból való távozás utáni hónapokban egyre fokozottabban jelentkezik.

Az asztmás tünetek gyakorisága és az alvási zavarok (gyakori felébredés) kevesebbszer fordultak elő a kezelés utáni 1 . és 2 . hónapban, mint az 5 . és a 6 . hónap elteltével. Míg az első hónap átlagértéke jónak mondható, 4,09 volt, és azt jelzi, hogy a betegek alvását csupán havi 1-2 alkalommal zavarta meg a nehézlégzés, addig a 6. hónapra az átlagérték 2,79-ra romlott. A 2-es és 3-as közötti érték mutatja, hogy fél év elteltével a betegek alvászavara, melyet a légzési problémák okoznak, sűrúbben jelentkezett, hetente egy vagy akár 2-3 alkalommal is. A magas szórásérték mutatja, hogy a betegek nem egységes válaszokat adtak (1. táblázat). Amennyiben összehasonlítottuk páros t-teszttel az asztmás tünetek alvásra kifejtett hatását a kezelés utáni 1 . és 3 . hónap eredményei alapján $(\mathrm{t}=14,79, \mathrm{df}=513, \mathrm{p}<0,001)$, illetve a 3 . és a 6 . hónap eredményeit $(\mathrm{t}=17,13, \mathrm{df}=513, \mathrm{p}<0,001)$, rendre szignifikáns eltérést kaptunk.

A komplex terápia egyik jelentős hatása, hogy a kezelés utáni 1 . és 2 . hónapban igen ritka, szinte egyáltalán nem jellemző a betegek rohamoldó-használata. A 6. hónap elteltével azonban a heti $2-3$ alkalommal történő használat lesz jellemző a mintában (1. táblázat). Összehasonlítottuk páros t-teszttel a rohamoldó használatának gyakoriságát a kezelés utáni 1 . és 3 . hónap eredményei $(\mathrm{t}=12,86 \mathrm{df}=516, \mathrm{p}<0,001)$, illetve a 3 . és a 6 . hónap eredményei alapján $(\mathrm{t}=14,99 \mathrm{df}=513, \mathrm{p}<0,001)$, és rendre szignifikáns eltérést kaptunk. Az asztmás betegek rohamoldó-használatának gyakorisága szignifikánsan megnő a kezelés után eltelt hónapokban.

Az, hogy összességében hogyan értékelik asztmás állapotukat a betegek az elmúlt 6 hónapban, az előző eredményekhez hasonlóan azt mutatta, hogy a kezelés utáni 1. és 2. hónapban a betegek jól érzik magukat, míg az 5., 6. hónap elteltével a 'nem vagyok jól' és a 'közepesen érzem magam' válaszok dominanciája figyelhető meg (1. táblázat). Az 1. és 3. hónap $(\mathrm{t}=18,053, \mathrm{df}=516$, $\mathrm{p}<0,001)$, valamint a 3 . és a 6 . hónap eredményeiben $(t=20,64, \mathrm{df}=516, \mathrm{p}<0,001)$ rendre szignifikáns eltérést tapasztaltunk.

Megvizsgáltuk az Asztma Kontroll Teszt összpontszámának átlagértékeit a kezelés utáni 1-6. hónapban. Amennyiben a teszt eredménye 25 pont, azt jelenti, hogy a beteg asztmás állapota teljes mértékben kontrollált, vagyis a páciens tünetmentes. Amennyiben a pontszám 20-24 közötti, úgy a beteg asztmás állapota részben kontrollált, vagyis a páciens jól van, de nem tünetmentes. A 20 alatt lévő érték azt mutatja, hogy a beteg asztmás állapota nem kontrollált, vagyis a páciens rosszul érzi magát a jelentkező tünetek miatt (1. táblázat). A saját és más hazai kutatás [4] is azt igazolta, hogy sajnos hazánkban is jelentősen elmarad az asztmás betegek kontrollszintje a kívánatostól, ami jelentős életminőségbeli korlátozást jelent a betegek számára. 


\section{Megbeszélés}

Kutatásunkkal igazolni tudtuk, hogy a Mátrai Gyógyintézetben történt komplex terápia az asztmás betegek állapotát javította: a FEVl-érték 6,15-tel, a FEVl/VC 3,18 -dal és a 6 perces járásteszt 77,18 m-rel történő emelkedése szignifikáns javulást igazolt. A nemzetközi irodalomban is végeztek a magaslati klímán fekvő intézetekben asztmás betegeken kontrollcsoport nélküli követéses vizsgálatokat, melyek elemszáma lényegesen alacsonyabb. Ezekben a nemzetközi vizsgálatokban is kimutathatóan javult a különböző időtartamú terápiás kezelés után az asztmás betegek állapota, amit az alábbiakban ismertetünk. A különböző magasságokban felnőtt személyeken végzett klímaterápiás kutatásoknak széles nemzetközi irodalmi hátterük van. Szlovákiában számos szakirodalmi publikáció foglalkozik az asztmások számának és a betegség prevalenciájának elemzésével, valamint annak terápiás kezelési lehetôségeivel [31-35]. A légutak obstruktív betegségei - a bronchialis asztma, az obstruktív tüdőbetegség és a krónikus hörghurut, valamint az ismert és ismeretlen okok miatt kialakult tüdőkárosodás - kezelése elsősorban farmakológiai alapú, azonban nem farmakológiai kezeléssel is nagyon hatásos lehet; Szlovákiában a természetes gyógytényezők használatakor a „spa-balneológiai kezelést” alkalmazzák az asztmás betegeken. Ennek lényege, hogy kombinálja a gyógytényezők (gyógyfürdő és magaslati klíma) különböző formáit. A Magas-Tátra éghajlati tényezóinek terápiás használatát több szlovák kutatás bemutatja. Zapletal és mtsai [36] 106 asztmás gyereknek (6-15 év) a Magas-Tátra területén (Dolny Smokoveci Gyermek Tüdő Intézet) történt 6-8 hetes klímaterápiás kezelésének pozitív hatásait mutatta ki, mindemellett megállapították, hogy a MEFVgörbék paraméterei alapján az asztmás gyermekek klimatikus terápiás hatásának tüdőfunkciójának objektív mércéjévé vált.

Pohanka és mtsai [37] a szlovákiai Sorban Intézetben (Magas-Tátra) 860-1010 méter tengerszint feletti magasságon 33 gyermeken (átlagéletkor $=10,6$ év, sd = $2,4)$ végeztek komplex klímaterápiás kutatást, amelyben az asztmás és a nem asztmás csoportban történt mérések során igazolni tudták, hogy a klímaterápiai eljárások képesek javítani a betegek életminóségét és a kezelés költséghatékonyságát. Bobokhozhdaev és Shirinskii [38] 1960 méterrel a tengerszint felett (Szovjetunió) 20 fó atópiás asztmás felnőtt betegen a 4 hetes klímaterápia pozitív hatását igazolták. Brimkulov [39] $3000 \mathrm{~m}$ tengerszint feletti magasságú helyen (Szovjetunió) 18-58 év közötti asztmás felnőttek $(\mathrm{n}=38)$ légzésfunkciójának változását mérte egy 4 hetes klímaterápia során, és megállapította, hogy a betegek légzésfunkciójában javulás következett be. Allegra és mtsai [40] Nepálban 4559-5050 méter közötti tengerszint feletti magasságban egyhetes klímaterápia hatását mérték 23-48 év közötti asztmás felnőtteken $(\mathrm{n}=11)$. Louie és Paré [41] ugyancsak Nepálban 4100 m-es magasságban 24 felnőtt asztmás beteget vizs- gált. 2 hét elteltével a PEFR- (eróltetett kilégzési csúcsáramlás) értékük az alábbiak szerint változott: átlag = $558(\mathrm{sd}=43)$, majd 2 hét múlva: átlag $=482(\mathrm{sd}=42)$.

Svájcban $1560 \mathrm{~m}$ tengerszint feletti magasságban végzett klímaterápia hatását 92 asztmás felnőttön vizsgálták, s 12 hetes kezelés során a FEV1\% jelentős javulását tapasztalták.

Hasonló javulásról számoltak be Seys és mtsai [42] Argentínában 18 asztmás felnőttnél 6965 m-en végzett 2 hetes, valamint Simon és mtsai [43] Svájcban 1560 m-en 8-15 év közötti asztmás gyerekek körében végzett klímaterápiás kutatásukban. Azóta több, Svájcban gyerekek körében elvégzett kutatás is megerősítette, hogy a klímaterápia után javulnak a gyerekek légzésfunkciós értékei $[44,45]$.

Napjainkban nemcsak a betegség kezelését tekintjük fontosnak, hanem az asztmások kapcsán is megfogalmazódik az életminőség javítása. A jólléttel, életminőséggel, boldogsággal kapcsolatos kutatások az 1970-es években vettek lendületet [46]. Az életminőségen belül a szubjektív jóllét az elmúlt évtizedekben szintén egyre nagyobb figyelmet kapott [47, 48]. Mára egyértelmúen megfogalmazódik az életminőségbeli javulás iránti igény a betegek körében is. Az asztmás betegek életminőségével foglalkozó kutatások széles skálája ismert $[4,5,8]$. A mi kutatásunkban is történt életminőség-vizsgálat, melyet az asztmásokra kifejlesztett ACT segítségével mértünk. Az intézményben történt terápia után a betegek életminőségében javulást tapasztaltunk. A terápia hatása az intézetben történő terápia utáni első hónapban a legerősebb, majd a hónapok elteltével a terápia hatása csökken, amit a betegek ACT-eredményei igazoltak.

\section{Következtetések}

A klímaterápiával egybekötött komplex terápia kedvezően hatott a betegek állapotára, kontrollszintjére, hiszen az intézetből való távozás utáni első hónapban szignifikánsan kevesebb rohamoldó-szükséglettel rendelkeztek, mint a 3. vagy a 6. hónap elteltével, és az állapotuk és közérzetük is a többi vizsgált mutatóban is hasonló eredményt tudott igazolni. A kutatás eredménye felhívja a figyelmet a 700 és 1000 méter tengerszint feletti magasságú mikroklíma és a komplex rehabilitáció kedvező hatására, valamint a természetes gyógytényezők szerepére (melyekhez orvosi terápia is társul), azok alkalmazására, ami segít csökkenteni a betegek és az egészségügyi ellátórendszer kiadásait.

A különböző éghajlati és klimatikus viszonyok szerepét és jelentőségét hangsúlyozza az asztmás tünetek előfordulásában, annak gyakoriságában és szezonális megjelenésében egy amerikai tanulmány is [49]. A klímaterápiás vizsgálatok - melyeket Arizonában, Tucsonban és Yumában, illetve a New Orleans-i, Louisianában élő asztmás gyermekeken végeztek - igazolták, hogy az asztmás exacerbatiók szezonális csúcsai eltérően alakulnak a különböző éghajlati, földrajzi helyeken élő gyermekek 
körében. Így a sajátos mikroklimatikus viszonyok, klímaterápia hatásai a gyógyhelyeken végzett terápiás kezeléseket befolyásolják, aminek ismerete nélkülözhetetlen az asztmás betegek kezelésében.

Anyagi támogatás: A közlemény elkészítését a GINOP-2.3.2-15-2016-00005. számú projekt támogatta. A projekt az Európai Unió támogatásával, az Európai Regionális Fejlesztési Alap társfinanszírozásával valósult meg.

Szerzôi munkamegosztás: M. A., B. B. É.: A koncepció és a kutatási terv kidolgozása. M. A., B. M., P. A.: Adatgyưjtés. M. A., B. I., Cs. L., B. Z., B. M., E. B., B. B. É.: Elemzés. B. M.: A kézirat szerkesztése. M. A., Cs. L., B. B. É.: A kézirat áttekintése. A közlemény végleges változatát valamennyi szerző elolvasta és jóváhagyta.

Érdekeltségek: A szerzőknek nincsenek érdekeltségeik.

\section{Irodalom}

[1] Somfay A. Healing strategies in asthma. What is the interest of the patient, the doctor, the authority and the manufacturer? [Kezelési stratégiák asztmában. Mi a beteg, az orvos, a hatóság és a gyártó érdeke?] Asztma - COPD-evidenciák. 2007. [Hungarian]

[2] The number of asthmatic patients is rising at an alarming place in Hungary. [Döbbenetes mértékben nő az asztmás betegek száma Magyarországon.] Országos Korányi TBC és Pulmonológiai Intézet, 2015. Available from: https://alfahir.hu/2017/03/03/ asztma_egeszsegugy_magyarorszag_allergia [accessed: November 15, 2017]. [Hungarian]

[3] Diseases in Northern Hungary (based on family medicine and home pediatric records). [Betegségek Észak-Magyarországon (háziorvosi és házi gyermekorvosi nyilvántartás alapján).] Központi Statisztikai Hivatal, Budapest, 2009. Available from: https://www.ksh.hu/docs/hun/xftp/idoszaki/regiok/miskolcbetegsegek.pdf [accessed: November 14, 2017]. [Hungarian]

[4] Mészáros Á. Life quality measurement in asthma bronchial. [Életminőség-mérés asthma bronchialéban.] LAM 2006; 16: 353-359. [Hungarian]

[5] Vincze G, Rascati KL, Vincze Z. Health-related quality of life assurance. In: Vincze Z, Káló Z, Bodrogi J. (eds.) [Egészséggel kapcsolatos életminőség-vizsgálatok. In: Vincze $Z$, Káló $Z$, Bodrogi J. (szerk.) Bevezetés a farmakoökonómiába.] Medicina Könyvkiadó, Budapest, 2001; pp. 187-209. [Hungarian]

[6] Ágh T. Therapy, quality of life and disease burden in chronic obstructive pulmonary disease. $\mathrm{PhD}$ thesis. [Terápiahúség, életminőség és betegségteher krónikus obstruktív tüdőbetegségben. PhD-értekezés.] Semmelweis Egyetem, Gyógyszertudományok Doktori Iskola, 2012. [Hungarian]

[7] Dinyáné Szabó M, Pusztai G. Use of the short (5-item) version of the WHO well-being questionnaire in first year students of Semmelweis University. [Az Egészségügyi Világszervezet öttételes jól-lét kérdő́ivének vizsgálata a Semmelweis Egyetem elsőéves hallgatóinak körében.] Orv Hetil. 2016; 157: 1762-1768. [Hungarian]

[8] Káló Z, Péntek M. Measurement of quality of life. In: Gulácsi L (ed.) Health economics. [Az életminőség mérése. In: Gulácsi L. (szerk.) Egészség-gazdaságtan.] Medicina Könyvkiadó, Budapest, 2005; pp. 161-189. [Hungarian]
[9] Jackson AS, Stanforth PR, Gagnon J, et al. The effect of sex, age and race on estimating percentage body fat from body mass index: The Heritage Family Study. Int J Obes Relat Metab Disord. 2002; 26: 789-796.

[10] Bíró Gy. (ed.) First Hungarian representative nutrition survey (1985-1988). National Institute of Food Hygiene and Nutrition. [Az első magyarországi reprezentatív táplálkozási vizsgálat (1985-1988).] OÉTI, Budapest, 1992. [Hungarian]

[11] Rurik I, Ungvári T, Szidor J, et al. Obese Hungary. Trend and prevalence of overweight and obesity in Hungary. 2015. [Elhízó Magyarország. A túlsúly és az elhízás trendje és prevalenciája Magyarországon. 2015.] Orv. Hetil. 2016; 157: 1248-1255. [Hungarian]

[12] Expert Panel Report 3 (EPR-3): Guidelines for the diagnosis and management of asthma - summary report 2007. National Asthma Education and Prevention Program. Allergy Clin Immunol. 2007; 120(Suppl): S94-S138. [Errátum: J Allergy Clin Immunol. 2008; 121: 1330.]

[13] Müller V, Gálffy G, Tamási L. Asthma and chronic obstructive pulmonary disease overlap. [Asthma bronchiale és krónikus obstruktív tüdőbetegség együttes megjelenése.] Orv Hetil. 2011; 152: 114-118. [Hungarian]

[14] Johnson JD, Theurer WM. A stepwise approach to the interpretation of pulmonary function tests. Am Fam Physician 2014; 89: 359-366.

[15] Stadtmauer GJ. ICS/LABA combination inhalers: the takehome message. Medscape. Oct 04, 2012.

[16] Miller-Larsson A, Selroos O. Advances in asthma and COPD treatment: combination therapy with inhaled corticosteroids and long-acting 32 -agonists. Curr Pharm Des. 2006; 12: 32613279.

[17] Enright PL, Sherrill DL. Reference equations for the six-minute walk in healthy adults. Am J Respir Crit Care Med. 1998; 158: 1384-1387.

[18] Pereira LF, Mancuzo EV, Rezende CF, et al. Six-minute walk test and respiratory muscle strength in patients with uncontrolled severe asthma: a pilot study. J Bras Pneumol. 2015; 41: 211-218.

[19] Morales-Blanhir JE, Palafox Vidal CD, Rosas Romero Mde J, et al. Six-minute walk test: a valuable tool for assessing pulmonary impairment. J Bras Pneumol. 2011; 37: 110-117.

[20] Simon A, Tiringer I, Berényi I, et al. Psychological factors considerably influence the results of 6-min walk test after coronary bypass surgery. [A pszichológiai tényezők jelentősen befolyásolják a 6 perces járásteszt eredményeit ACBG-mútét után.] Orv Hetil. 2007; 148: 2087-2094. [Hungarian]

[21] Tulassay Zs. [Fundamentals of internal medicine 1.] A belgyógyászat alapjai 1.] Medicina Könyvkiadó, Budapest, 2010. [Hungarian]

[22] Schatz M, Sorkness CA, Li JT, et al. Asthma Control Test: reliability, validity, and responsiveness in patients not previously followed by asthma specialists. Allergy Clin Immunol. 2006; 117: 549-556.

[23] Al-Qerem W, Pullen R, McGarry K, et al. Reported prevalence of allergy and asthma in children from urban and rural Egypt. Air Qual Atmosphere Health 2016; 9: 613-620.

[24] Brunekreef B, Stewart AW, Anderson HR, et al. Self-reported truck traffic on the street of residence and symptoms of asthma and allergic disease: A global relationship in ISAAC phase 3. Environ Health Perspect 2009; 117: 1791-1798.

[25] Wang KY, Chau TT. An association between air pollution and daily outpatient visits for respiratory disease in a heavy industry area. PLoS ONE 2013; 25: e75220.

[26] Smith KR, Bruce N, Balakrishnan K, et al. Millions dead: how do we know and what does it mean? Methods used in the comparative risk assessment of household air pollution. Annu Rev Public Health 2014; 35: 185-206.

[27] Lee A, Kinney P, Chillrud S, et al. A systematic review of innate immunomodulatory effects of household air pollution secondary 
to the burning of biomass fuels. Ann Glob Health 2015; 81: $368-374$.

[28] Air Working Group. Combustion-related air pollution and elimination options V 1. 31. (combustion, incineration, combustion of agricultural waste, wood combustion). [Levegő Munkacsoport. Égetés eredetû́ légszennyezés és megszüntetésének lehetőségei V 1. 31. (avarégetés, hulladékégetés, mezőgazdasági eredetű hulladékok égetése, fatüzelés).] Available from: https:// www.levego.hu/sites/default/files/egetes_eredetu_legszennyezes_program_v_1.3.pdf [accessed: November 14, 2017]. [Hungarian]

[29] Gálffy G, Orosz M, Tamási L. The importance of Asthma Control Test in assessing the quality of life of asthmatic patients in Hungary. [Az Asthma Control Test jelentősége az asztmás betegek életminőségének felmérésében hazai beteganyagon.] Allergol Klin Immunol. 2009; 12: 11-15. [Hungarian]

[30] Cohn SH. New concepts of body composition. In: Ellis KJ, Yasumura S, Morgan WD. (eds.) In vivo body composition studies. The Institute of Physical Sciences in Medicine, London, 1987; pp. 1-14.

[31] Bergendiová K. Drugdová, M. Bronchiálna asthma. [Bronchiálna astma.] Pediatr prax. 2007; 4: 193-196. [Slovakian]

[32] Hrubiško M. Asthma under control: Do we know what it is and how to do it? [Astma pod kontrolou: Vieme čo to je a ako na to?] Ambulantná terapia 2008; 6: 8-13. [Slovakian]

[33] Hrubiško M, Rozborilová E, Pružinec P, et al. Asthma control and overview of treatment in the Slovak Republic, 2006. [Kontrola astmy a prehlad terapie v Slovenskej republike v r. 2006.] Medicínsky monitor. 2007; 1: 20-24. [Slovakian]

[34] Kajtár P. Current guidelines for the diagnosis and treatment of community-acquired pneumonia. [Súčasné odporúčania na diagnostiku a liečbu komunitných pneumónií.] Via pract. 2015; 12 : 64-70. [Slovakian]

[35] Laššán Š, Laššánová M. Severe pneumococcal respiratory infections and their prevention. [Závažné pneumokokové respiračné infekcie a ich prevencia.] Respiro 2013; 2: 9-13. [Slovakian]

[36] Zapletal A, Pohanka V, Zbojan J. et al. The effect of a high-altitude climate on the function of the respiratory system in children with asthma. Cesk Pediatr. 1992; 47: 357-362.

[37] Pohanka V, Pohanka M, Fleischer P, et al. The role of the climate in complex treatment of respiratory disease. Zdrowie Publiczne i Zarządzanie 2012; 10: 9-12.

[38] Bobokhozhdaev OI, Shirinskii VS. The efficacy of treating bronchial asthma patients at Khodzhaobigarm health resort. [Effektivnost' lecheniia bol'nykh bronkhial'noi astmoi na kurorte Khodzhaobigarm.] Vopr Kurortol Fizioter Lech Fiz Kult. 1990; 6: 21-26. [Russian]
[39] Brimkulov NN. The alpine climatotherapy of bronchial asthma patients. [Vysokogornaia klimatoterapiia bol'nykh bronkhial'noi astmoi.] Ter Arkh. 1991; 63: 25-30. [Russian]

[40] Allegra L, Cogo A, Legnani D, et al. High altitude exposure reduces bronchial responsiveness to hypo-osmolar aerosol in lowland asthmatics. Eur Respir J. 1995; 8: 1842-1846.

[41] Louie D, Paré PD. Physiological changes at altitude in nonasthmatic and asthmatic subjects. Can Respir J. 2004; 11: 197-199.

[42] Seys SF, Daenen M, Dilissen E, et al. Effects of high altitude and cold air exposure on airway inflammation in patients with asthma. Thorax 2013; 68: 906-913.

[43] Simon HU, Grotzer M, Nikolaizik WH, et al. High altitude climate therapy reduces peripheral blood $\mathrm{T}$ lymphocyte activation, eosinophilia, and bronchial obstruction in children with housedust mite allergic asthma. Pediatr Pulmonol. 1994; 17: 304311.

[44] Grootendorst DC, Dahlen SE, Van Den Bos JW, et al. Benefits of high altitude allergen avoidance in atopic adolescents with moderate to severe asthma, over and above treatment with high dose inhaled steroids. Clin Exp Allergy 2001; 31: 400-408.

[45] Straub DA, Ehmann R, Hall GL, et al. Correlation of nitrites in breath condensates and lung function in asthmatic children. Pediatr Allergy Immunol. 2004; 15: 20-25.

[46] Campbell A. Subjective measures of well-being. Am Psychol. 1976; 31: 117-124.

[47] Kopp M, Martos T. The significance and potential of social cohesion in today's Hungarian society I. Quality of life, economic development and the National Comparative Index. [A társadalmi összjóllét jelentősége és vizsgálatának lehetőségei a mai magyar társadalomban I. Életminőség, gazdasági fejlődés és a Nemzeti Összjólléti Index.] Mentálhig Pszichoszom. 2011; 12: 241-259. [Hungarian]

[48] Michalkó G. The intergenerational foundations of well-being: social interaction in Hungary. [Boldogító utazás: a turizmus és az életminőség kapcsolatának magyarországi vonatkozásai.] MTA Földrajztudományi Kutatóintézet, Budapest, 2010; pp. 16-40. [Hungarian]

[49] Wisniewski JA, McLaughlin AP, Stenger PJ, et al. A comparison of seasonal trends in asthma exacerbations among children from geographic regions with different climates. Allergy Asthma Proc. 2016; 37: 475-481.

(Müller Anetta dr., Debrecen, Böszörményi út 138., 4032 e-mail: muller.anetta@econ.unideb.hu)

\section{"Mane petas montes, medio nemus, vespera fontes!" (Reggel a hegyekbe, délben az erdőbe, este a folyóhoz menj!)}

